\title{
Modernisasi Perpajakan terhadap Kepatuhan Wajib Pajak Orang Pribadi dengan Pemahaman Internet sebagai Variabel Pemoderasi
}

\author{
Ni Kadek Indah Amiliasari ${ }^{1}$ \\ Fakultas Ekonomi dan Bisnis \\ Universitas Udayana, Indonesia
}

\author{
Putu Ery Setiawan ${ }^{2}$ \\ Fakultas Ekonomi dan Bisnis \\ Universitas Udayana, Indonesia
}

\begin{abstract}
Surel : dekindah18@gmail.com
ABSTRAK

E-system adalah modernisasi sistem perpajakan yang menggunakan teknologi informasi yang memermudah wajib pajak dalam melaporkan dan membayar pajaknya. E-system terdiri dari e-registration, e-SPT, e-filing, dan e-billing. Penelitian ini bertujuan untuk memeroleh bukti empiris pengaruh $e$ registration, e-SPT, e-filing, dan e-billing terhadap kepatuhan WPOP dengan pemahaman internet sebagai variabel moderasi. Incidental sampling adalah metode penentuan sampel yang digunakan. Analisis regresi linier berganda dan Moderated Regression Analysis (MRA) merupakan teknik analisis dalam penelitian ini. Hasil penelitian menunjukkan e-registration, $e-S P T$, e-filing, dan e-billing berpengaruh positif terhadap kepatuhan WPOP sedangkan pemahaman internet tidak dapat memoderasi hubungan antara e-registration, e-SPT, e-filing, dan e-billing terhadap kepatuhan WPOP.

Kata Kunci: Registration; E-SPT; E-Filing, E-Billing; Kepatuhan Wajib Pajak; Pemahaman Internet.

\section{Tax Modernization on Individual Taxpayer Compliance with an Understanding of the Internet as a Moderating Variable}

\footnotetext{
ABSTRACT

E-system is a modernization of taxation system that uses information technology that makes it easier for taxpayers to report and pay their taxes. E-system consists of e-registration, e-SPT, e-filing, and e-billing This study aims to determine the effect of e-registration, e-SPT, e-filing, and e-billing on the compliance of individual taxpayers with internet understanding as moderating variable. Determination of the number of samples using incidental sampling technique. Linear regression test and Moderated Regression Analysis (MRA) are the data analysis technique $u s e d$. The results showed that e-registration, e-SPT, e-filing, and ebilling has a positive effect on the compliance of individual taxpayers meanwhile e-registration, e-SPT, e-filing, and e-billing was not moderated by internet understanding on the compliance of individual taxpayers.

Keywords: E-registration; E-SPT; E-filing; E-billing; Taxpayer Compliance; Internet Understanding.
}

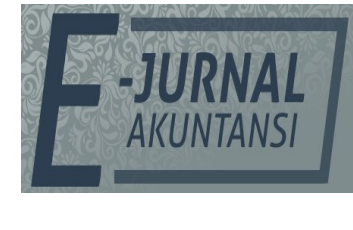

e-ISSN 2302-8556

Vol. 31 No. 7

Denpasar, Juli 2021 Hal. 1644-1654

DOI:

10.24843/EJA.2021.v31.i07.p03

PENGUTIPAN:

Amiliasari, N.K.I., \&

Setiawan, P.E. (2021).

Modernisasi Perpajakan terhadap Kepatuhan Wajib Pajak Orang Pribadi dengan Pemahaman Internet sebagai Variabel Pemoderasi. E-Jurnal Akuntansi, 31(7), 1644-1654

\section{RIWAYAT ARTIKEL:}

Artikel Masuk: 29 November 2020 Artikel Diterima: 17 Februari 2021

Artikel dapat diakses : https://ojs.unud.ac.id/index.php/Akuntansi/index 


\section{PENDAHULUAN}

Indonesia merupakan salah satu negara berkembang yang sedang aktif melakukan pembangunan Sumber Daya Manusia (SDM) dan infrastruktur. Kegiatan pembangunan memerlukan dana yang memadai yang diperoleh melalui sektor penerimaan negara. Berdasarkan data Badan Pusat Statistik (2020) jumlah penerimaan negara dari tahun 2015 sampai tahun 2019 dapat dilihat pada Tabel 1, berikut.

Tabel 1. Penerimaan Negara (Milyar Rupiah)

\begin{tabular}{cccccc}
\hline & Tahun & $\begin{array}{c}\text { Penerimaan } \\
\text { Perpajakan }\end{array}$ & $\begin{array}{c}\text { Penerimaan } \\
\text { Bukan Pajak }\end{array}$ & Hibah & Jumlah \\
\hline \multirow{2}{*}{2015} & Nilai & 1.240 .419 & 255.628 & 11.973 & 1.508 .020 \\
& Persentase (\%) & 82 & 17 & 1 & 100 \\
\multirow{2}{*}{2016} & Nilai & 1.284 .970 & 261.976 & 8.988 & 1.555 .934 \\
\multirow{2}{*}{2017} & Persentase (\%) & 83 & 17 & 1 & 100 \\
& Nilai & 1.343 .530 & 311.216 & 11.630 & 1.666 .376 \\
2018 & Persentase (\%) & 81 & 19 & 1 & 100 \\
& Nilai & 1.518 .790 & 409.320 & 15.565 & 1.943 .675 \\
2019 & Persentase (\%) & 78 & 21 & 1 & 100 \\
& Nilai & 1.643 .084 & 386.334 & 1.340 & 2.030 .758 \\
\end{tabular}

Sumber: Badan Pusat Statistik, 2020

Berdasarkan Tabel 1, sebesar 81 persen penerimaan negara berasal dari sektor perpajakan, sehingga pajak merupakan penerimaan negara yang paling potensial (Krisnayanti \& Yuesti, 2019).

Kurangnya kesadaran wajib pajak dalam melaporkan dan membayar pajaknya menyebabkan menurunnya penerimaan perpajakan, salah satu yang menyebabkan hal tersebut terjadi adalah rumit dan lamanya sistem administrasi perpajakan yang menyita waktu wajib pajak sehingga wajib pajak enggan untuk datang ke kantor pajak. Pemerintah melalui Direktorat Jenderal Pajak (DJP) terus melakukan pembaruan dalam sektor perpajakan. Salah satunya melakukan modernisasi sistem perpajakan yang memanfaatkan teknologi yang disebut dengan e-system perpajakan. Teori Unified Theory of Acceptance and Use of Technology (UTAUT) menjelaskan bahwa niat seseorang untuk menggunakan suatu teknologi ditentukan oleh kemudahan yang didapat terkait dengan penggunaan suatu teknologi E-system dalam perpajakan terdiri dari e-registration, e-SPT, e-billing, dan e-filing (Purnamasari \& Hindria, 2018).

Pendaftaran wajib pajak untuk memeroleh NPWP secara daring disebut dengan e-registration. E-SPT adalah aplikasi pengisian Surat Pemberitahuan Tahunan (SPT) secara daring. E-filing adalah penyampaian SPT secara daring. Ebilling merupakan metode pembayaran pajak secara daring. Penerapan e-system perpajakan memanfaatkan jaringan internet. Pemahaman mengenai internet akan membantu wajib pajak dalam menggunakan e-system perpajakan (Josiah et al., 2020).

Kepatuhan WPOP yang mengalami tren penurunan dari tahun 2015 - 2019 yaitu KPP Pratama Gianyar. Tingkat kepatuhan WPOP di KPP Pratama Gianyar yang ditunjukkan pada Tabel 2, berikut. 
Tabel 2. Tingkat Kepatuhan Wajib Pajak Orang Pribadi di KPP Pratama Gianyar Tahun 2015 - 2019.

\begin{tabular}{cccccc}
\hline No & Tahun & $\begin{array}{c}\text { WPOP } \\
\text { Terdaftar }\end{array}$ & $\begin{array}{c}\text { WPOP } \\
\text { Efektif }\end{array}$ & $\begin{array}{c}\text { WPOP yang } \\
\text { Menyampaikan SPT }\end{array}$ & $\begin{array}{c}\text { Kepatuhan } \\
(\%)\end{array}$ \\
\hline 1 & 2015 & 114.677 & 91.375 & 65.776 & 71,98 \\
2 & 2016 & 125.113 & 100.095 & 64.927 & 64,87 \\
3 & 2017 & 163.886 & 108.439 & 64.435 & 59,42 \\
4 & 2018 & 166.458 & 119.546 & 66.541 & 55,66 \\
5 & 2019 & 167.801 & 132.924 & 58.618 & 44,10 \\
\hline
\end{tabular}

Sumber: KPP Pratama Gianyar, 2020

Berdasarkan Tabel 2, diketahui bahwa belum 100 persen wajib pajak memiliki kepatuhan dalam membayar pajaknya. Jumlah Wajib Pajak Orang Pribadi (WPOP) terdaftar dan efektif dari tahun 2015 - 2019 terus mengalami peningkatan, sedangkan WPOP yang menyampaikan SPT mengalami penurunan.

Teori UTAUT dikembangkan oleh Venkatesh pada tahun 2003 berdasarkan model-model penerimaan teknologi yang sudah ada (Hakim, 2016) yang digunakan untuk menjelaskan niat sesorang untuk menggunakan suatu teknologi dan perilaku pengguna selanjutnya. Teori UTAUT memiliki empat penentu utama (core determinants) niat seseorang dalam menggunakan suatu teknologi. Keempat hal tersebut menjelaskan bahwa seseorang akan menggunakan e-system perpajakan apabila orang tersebut percaya bahwa dengan menggunakan teknologi tersebut akan mampu memberikan kualitas dan efektifitas kemudahan dalam pekerjaannya.

E-registration memermudah wajib pajak dalam pendaftaran, pengubahan, dan penghapusan data wajib pajak, karena dilakukan secara daring yang memingkinkan wajib pajak dapat melakukan pendaftaran kapan saja dan dimana saja. Teori UTAUT menyebutkan bahwa niat seseorang menggunakan suatu teknologi dipengaruhi oleh kemudahan yang akan didapat terkait dengan penggunaan suatu sistem teknologi. Wajib pajak akan menggunakan e-system perpajakan apabila e-system perpajakan memberikan kemudahan dalam memenuhi kewajiban perpajakan.

$\mathrm{H}_{1}$ : E-registration berpengaruh positif terhadap kepatuhan wajib pajak orang pribadi.

E-SPT dibuat oleh DJP untuk memermudah wajib pajak dalam mengisi SPT secara daring dimana saja dan kapan saja. Niat seseorang menggunakan suatu teknologi dipengaruhi oleh kemudahan yang diperoleh dari penggunaan teknologi tersebut menurut teori UTAUT. Wajib pajak akan menggunakan $e$ system perpajakan apabila e-system perpajakan memberikan kemudahan dalam memenuhi kewajiban perpajakan.

$\mathrm{H}_{2}$ : E-SPT berpengaruh positif terhadap kepatuhan wajib pajak orang pribadi.

Penggunaan sistem $e$-filling akan memermudah wajib pajak melaporkan SPT Tahunan tanpa harus ke kantor pajak. Teori UTAUT menjelaskan bahwa seseorang akan menggunakan suatu sistem teknologi jika, sistem teknologi tersebut mampu memermudah dalam melakukan pekerjaannya. Wajib pajak akan menggunakan e-system perpajakan apabila e-system perpajakan memberikan kemudahan dalam memenuhi kewajiban perpajakan.

$\mathrm{H}_{3}$ : E-filling berpengaruh positif terhadap kepatuhan wajib pajak orang pribadi. 
Penggunaan $e$-billing dalam pembayaran atau penyetoran pajak yang tidak harus datang ke kantor pajak akan memermudah wajib pajak dalam memenuhi kewajiban perpajakan. Suatu sistem teknologi akan digunakan oleh seseorang jika sistem teknologi tersebut mampu memermudah dalam melakukan pekerjaannya. Hal tersebut dijelaskan oleh teori UTAUT. Wajib pajak akan menggunakan $e-$ system perpajakan apabila e-system perpajakan memberikan kemudahan dalam memenuhi kewajiban perpajakan.

$\mathrm{H}_{4}$ : E-billing berpengaruh positif terhadap kepatuhan wajib pajak orang pribadi.

E-system perpajakan ini yang terdiri dari e-registration, e-SPT, e-filling, dan ebilling tidak lepas dari penggunaan teknologi dan juga internet. Pemahaman mengenai internet akan membantu wajib pajak untuk menggunakan e-system perpajakan. Teori UTAUT menjelaskan bahwa suatu sistem teknologi dapat diterima oleh seseorang, apabila orang tersebut memiliki pengetahuan dan pemahaman yang baik dalam menggunakan teknologi tersebut. Wajib pajak yang memiliki pengetahuan dan pemahaman yang baik akan mendorong wajib pajak untuk menggunakan $e$-system perpajakan.

$\mathrm{H}_{5}$ : Pemahaman internet memoderasi (memperkuat) pengaruh e-registration terhadap kepatuhan wajib pajak orang pribadi.

$\mathrm{H}_{6}$ : Pemahaman internet memoderasi (memperkuat) pengaruh $e$-SPT terhadap kepatuhan wajib pajak orang pribadi.

$\mathrm{H}_{7}$ : Pemahaman internet memoderasi (memperkuat) pengaruh $e$-filing terhadap kepatuhan wajib pajak orang pribadi.

$\mathrm{H}_{8}$ : Pemahaman internet memoderasi (memperkuat) pengaruh e-biling terhadap kepatuhan wajib pajak orang pribadi.

\section{METODE PENELITIAN}

Penelitian ini dilakukan di KPP Pratama Gianyar. Objek penelitian dalam penelitian ini adalah kepatuhan WPOP. Penelitian ini menggunakan jenis data kuantitatif dan data primer berupa jawaban responden yang diperoleh dari kuesioner yang disebar dan diukur dengan skala likert 5 poin. Populasi yang digunakan dalam penelitian ini adalah WPOP yang terdaftar di KPP Pratama Gianyar berjumlah 167.801 orang. Jumlah sampel dalam penelitian ini adalah 100 responden yang ditentukan dengan rumus slovin. Metode penentuan sampel yang digunakan dalam penelitian ini adalah incidental sampling. Teknik analisis yang digunakan yaitu analisis regresi linier berganda dengan persamaan regresi sebagai berikut.

$Y=\alpha+\beta_{1} X_{1}+\beta_{2} X_{2}+\beta_{3} X_{3}+\beta_{4} X_{4}+\varepsilon$

Moderated Regression Analysis (MRA) adalah uji interkasi yang digunakan dalam penelitian ini. Persamaan regresi yang digunakan adalah sebagai berikut. $Y=\alpha+\beta_{1} X_{1}+\beta_{2} X_{2}+\beta_{3} X_{3}+\beta_{4} X_{4}+\beta_{5} Z+\beta_{6} X_{1} Z+\beta_{7} X_{2} Z+\beta_{8} X_{3} Z+\beta_{9} X_{4} Z+\varepsilon$ Keterangan:

Y

a

$\beta_{1,2,3,4,5,6,7,8,9}$

$\mathrm{X}_{1}$

$\mathrm{X}_{2}$

$\mathrm{X}_{3}$
$=\mathrm{WPOP}$

$=$ Konstanta

$=$ Koefisien regresi variabel bebas

$=$ E-registration

$=E-S P T$

$=$ E-filling 


$$
\begin{array}{ll}
\mathrm{X}_{4} & =\text { E-billing } \\
\mathrm{Z} & =\text { Variabel moderasi } \\
\varepsilon & =\text { Error term }
\end{array}
$$

\section{HASIL DAN PEMBAHASAN}

Hasil dari uji validitas menunjukkan bahwa instrumen penelitian yang digunakan untuk mengukur variabel e-registration, e-SPT, e-billing, e-filing, kepatuhan wajib pajak dan pemahaman internet dinyatakan valid, karena nilai pearson correlation dari masing-masing variabel lebih besar dari 0,30. Hasil uji reliabilitas dari seluruh variabel dinyatakan reliabel, karena nilai Cronbach's Alpha lebih besar dari 0,70. Pengujian normalitas dilakukan dengan uji Kolmogrov-Smirnov, dengan nilai Asymp. Sig. (2-tailed) yaitu 0,200 >0,05. Hal tersebut menunjukkan bahwa model persamaan regresi dalam penelitian ini berdistribusi normal. Hasil dari uji multikolinieritas didapat bahwa nilai tolerance dari variabel bebas $\geq 0,10$ dan nilai $\mathrm{VIF} \leq 10$. Hal tersebut menunjukkan model regresi pada penelitian ini tidak terjadi gejala multikolonieritas. Uji heteroskedastisitas dilakukan dengan uji Glejser, dimana mendapatkan hasil nilai sig. dari masing-masing variabel lebih besar dari 0,05 . Hal tersebut menunjukkan bahwa model regresi yang digunakan dalam penelitian ini tidak terjadi gelaja heteroskedastisitas.

Hasil uji analisis regresi linier berganda dapat dilihat pada Tabel 3, berikut. Tabel 3. Hasil Uji Analisis Regresi Linier Berganda

\begin{tabular}{ccccccc}
\hline \multirow{2}{*}{ Model } & \multicolumn{2}{c}{$\begin{array}{c}\text { Unstandardized } \\
\text { Coefficients }\end{array}$} & $\begin{array}{c}\text { Standardized } \\
\text { Coefficients }\end{array}$ & \multirow{2}{*}{$t$} & & \multirow{2}{*}{ Sig. } \\
\cline { 2 - 4 } & $\mathrm{B}$ & Std. Error & Beta & & & \\
\cline { 2 - 4 } 1 & (Constant) & $-3,842$ & 2,061 & & $-1,864$ & 0,401 \\
& $\mathrm{X}_{1}$ & 0,654 & 0,087 & 0,385 & 7,527 & 0,000 \\
& $\mathrm{X}_{2}$ & 0,470 & 0,082 & 0,290 & 5,717 & 0,000 \\
& $\mathrm{X}_{3}$ & 0,504 & 0,077 & 0,338 & 6,562 & 0,000 \\
& $\mathrm{X}_{4}$ & 0,387 & 0,087 & 0,224 & 4,439 & 0,000 \\
& Adjusted $R^{2}$ & & 80,2 & & & \\
& F Hitung & & 101,116 & & & \\
& Sig. F & & 0,000 & & & \\
\hline
\end{tabular}

Sumber: Data Penelitian, 2020

Berdasarkan Tabel 3, persamaan regresi linier berganda yang didapat yaitu sebagai berikut.

$$
Y=-3,842+0,654 X_{1}+0,470 X_{2}+0,504 X_{3}+0,387 X_{4}+\varepsilon
$$

Konstanta memiliki nilai negatif sebesar $-3,842$ yang menunjukkan apabila e-registration, e-SPT, e-filling, dan e-billing bernilai nol, maka kepatuhan WPOP akan sebesar $-3,842$.

Variabel $e$-registration memeroleh nilai beta positif sebesar 0,654 yang artinya apabila e-registration meningkat sebanyak satu satuan, maka kepatuhan WPOP naik sebesar 0,654 satuan. Variabel $e$-SPT memeroleh nilai beta positif sebesar sebesar 0,470 memiliki arti apabila $e-S P T$ meningkat satu satuan, maka kepatuhan WPOP akan naik sebesar 0,470 satuan. Variabel $e$-filing memeroleh nilai beta positif sebesar 0,504 menunjukkan apabila e-filing naik sebesar satu satuan, maka kepatuhan WPOP akan naik sebesar 0,504 satuan. Variabel $e$-billing memeroleh nilai koefisien regresi positif sebesar sebesar 0,387 menunjukkan bila e-billing naik sebesar satu satuan, maka kepatuhan WPOP naik sebesar 0,387 satuan. 
Nilai Adjusted R Square sebesar 0,802 atau sebesar 80,2 persen. Hal tersebut menunjukkan bahwa variabel kepatuhan wajib pajak orang pribadi dapat dijelaskan sebesar 80,2 persen oleh variabel bebas yang digunakan. Sisanya sebesar 19,8 persen dipengaruhi oleh faktor lain diluar penelitian ini. Nilai Sig. F sebesar 0,000 < 0,05. Maka dapat disimpulkan bahwa variabel bebas yang digunakan secara simultan berpengaruh terhadap kepatuhan wajib pajak orang pribadi.

Variabel e-registration memiliki pengaruh positif terhadap kepatuhan WPOP. Hal ini tercermin dari nilai sig. ( $t$ ) sebesar 0,000 yaitu lebih kecil dari 0,05. Hal tersebut menunjukkan bahwa $\mathrm{H}_{1}$ diterima. Keberadaan e-registration memberikan kemudahan wajib pajak dalam hal pendaftaran, pengukuhan \& pencabutan, serta perubahan data wajib pajak. Hal tersebut dikarenakan eregistration dapat dilakukan dimana saja dan kapan saja. Dikaitkan dengan Teori UTAUT mengenai ekspektasi terhadap upaya e-registration terbukti memberikan kemudahan bagi wajib pajak sehingga diharapkan mampu untuk meningkatkan kepatuhan wajib pajak. Hasil penelitian ini sejalan dengan penelitian yang dilakukan oleh Putra (2015), bahwa "penerapan sistem administrasi e-registration memiliki pengaruh signifikan terhadap tingkat kepatuhan wajib pajak".

Variabel $e-S P T$ memiliki nilai signifikansi $(t)$ sebesar 0,000 yang lebih kecil dari 0,05 . Hal tersebut mencerminkan bahwa $e-S P T$ berpengaruh positif terhadap kepatuhan wajib pajak orang pribadi, sehingga hipotesis kedua $\left(\mathrm{H}_{2}\right)$ diterima. ESPT yang dikeluarkan oleh DJP memermudah wajib pajak dalam pengisian SPT karena dilakukan dimana saja serta kapan saja. Jika dikaitkan dengan teori UTAUT mengenai kemudahan yang didapat dalam menggunakan suatu sistem atau teknologi, keberadaan aplikasi $e-S P T$ dapat memermudah wajib pajak dalam melaksanakan kewajiban perpajakan, sehingga diharapkan mampu untuk meningkatkan kepatuhan wajib pajak. Penelitian ini didukung oleh penelitian Sabil et al. (2018) yaitu penerapan e-SPT Pajak Penghasilan (PPh) orang pribadi berpengaruh secara signifikan terhadap kepatuhan wajib pajak.

Variabel $e$-filing memiliki pengaruh positif terhadap kepatuhan WPOP. Hal ini tercermin dari nilai sig. ( $\mathrm{t}$ ) sebesar 0,000 yang lebih kecil dari 0,05 , sehingga $\mathrm{H}_{3}$ diterima. E-filing memberikan kemudahan bagi wajib pajak dalam pelaporan SPT karena melalui e-filing, pelaporan SPT tidak perlu datang ke kantor pajak yang menyita banyak waktu namun dapat dilakukan dimana saja secara daring. Penelitian ini didukung oleh teori UTAUT mengenai ekspektasi terhadap usaha yang akan memermudah atau memersulit suatu pekerjaan dengan diterapkannya suatu teknologi. Adanya aplikasi $e$-filing mampu memermudah wajib pajak dalam melaksanakan kewajiban perpajakan. Hasil penelitian ini didukung oleh penelitian yang dilakukan oleh Agustiningsih \& Isroah (2016) adalah penerapana e-filing berpengaruh positif dan signifikan terhadap kepatuhan wajib pajak.

Variabel e-billing memiliki nilai signifikansi (t) sebesar 0,000 yang lebih kecil dari 0,05 . Hal tersebut mencerminkan bahwa $\mathrm{H}_{4}$ diterima. Penggunaan e-billing memberikan kemudahan bagi wajib pajak dalam membayar pajak karena dapat dilakukan tanpa harus datang ke kantor pajak. Penelitian ini didukung oleh teori UTAUT mengenai ekspektasi terhadap usaha yang mampu memberikan kemudahan dalam melaksanakan suatu pekerjaan. E-billing mampu memberikan kemudahan dan keamanan bagi wajib pajak dalam membayar pajak karena dapat 
dilakukan secara daring. Keberadaan e-billing memermudah wajib pajak melaksanakan kewajiban perpajakan yang diharapkan mampu meningkatkan kepatuhan wajib pajak. Penelitian ini didukung oleh Dewi et al. (2019) dengan hasil penelitian yaitu sistem $e$-billing berpengaruh signifikan terhadap kepatuhan wajib pajak. berikut.

Hasil Uji Moderated Regression Analysis (MRA) dapat dilihat pada Tabel 4, Tabel 4. Hasil Uji Moderated Regression Analysis (MRA)

\begin{tabular}{|c|c|c|c|c|c|c|}
\hline \multirow[t]{2}{*}{ Model } & \multicolumn{2}{|c|}{$\begin{array}{c}\text { Unstandardized } \\
\text { Coefficients }\end{array}$} & \multirow{2}{*}{$\begin{array}{c}\begin{array}{c}\text { Standardized } \\
\text { Coefficients }\end{array} \\
\text { Beta }\end{array}$} & \multirow[t]{2}{*}{$t$} & \multicolumn{2}{|c|}{ Sig. } \\
\hline & B & Std. Error & & & & \\
\hline \multirow{13}{*}{1} & (Constant) & $-21,106$ & 16,506 & & $-1,279$ & 0,204 \\
\hline & $\mathrm{X}_{1}$ & 0,161 & 0,634 & 0,095 & 0,255 & 0,800 \\
\hline & $X_{2}$ & 1,864 & 0,794 & 1,148 & 2,347 & 0,021 \\
\hline & $x_{3}$ & 1,245 & 0,914 & 0,835 & 1,361 & 0,177 \\
\hline & $X_{4}$ & $-0,304$ & 0,722 & $-0,176$ & $-0,422$ & 0,674 \\
\hline & $\mathrm{Z}$ & 0,758 & 0,669 & 0,428 & 1,133 & 0,260 \\
\hline & $X_{1} * Z$ & 0,019 & 0,025 & 0,407 & 0,753 & 0,453 \\
\hline & $X_{2} * Z$ & $-0,056$ & 0,031 & $-1,201$ & $-1,819$ & 0,072 \\
\hline & $\mathrm{X}_{3}{ }^{*} \mathrm{Z}$ & $-0,031$ & 0,036 & $-0,721$ & $-0,857$ & 0,394 \\
\hline & $\mathrm{X}_{4} * \mathrm{Z}$ & 0,028 & 0,029 & 0,563 & 0,936 & 0,352 \\
\hline & Adjusted $R^{2}$ & & 0,805 & & & \\
\hline & F Hitung & & 46,466 & & & \\
\hline & Sig. F & & 0,000 & & & \\
\hline
\end{tabular}

Sumber: Data Penelitian, 2020

Berdasarkan hasil analisis Moderated Regression Analysis (MRA) pada Tabel 4, didapatkan hasil persamaan sebagai berikut.

$Y=-21,106+0,161 X_{1}+1,864 X_{2}+1,245 X_{3}-0,304 X_{4}+0,758 Z+0,019 X_{1} Z-0,056 X_{2} Z-$ $0,031 X_{3} Z+0,328 X_{4} Z+\varepsilon$

Konstanta yang bernilai negatif sebesar -21,106 artinya apabila variabel bebas yang digunakan sama dengan nol, maka kepatuhan WPOP sebesar -21.106.

Kepatuhan wajib pajak orang pribadi akan naik sebesar 0,758 satuan, jika variabel pemahaman internet memeroleh nilai koefisien regresi yang positif sebesar 0,758.

Variabel interaksi $X_{1} Z$ memeroleh nilai koefisien regresi positif sebesar 0,019 menunjukkan apabila nilai variabel interaksi $X_{1} Z$ naik satu satuan, maka kepatuhan WPOP naik sebesar 0,019 satuan. Variabel interaksi $X_{2} Z$ memeroleh nilai koefisien regresi negatif sebesar -0,056 mencerminkan apabila nilai variabel interaksi $X_{2} Z$ naik satu satuan, maka kepatuhan WPOP akan menurun sebesar 0,056 satuan. Variabel interaksi $X_{3} Z$ memeroleh nilai koefisien regresi negatif 0,031 berarti apabila nilai variabel interaksi $X_{3} Z$ bertambah satu satuan, maka kepatuhan WPOP akan menurun sebesar 0,031 satuan. Variabel interaksi $X_{4} Z$ memeroleh nilai koefisien regresi positif sebesar 0,028 menunjukkan apabila nilai variabel interaksi $\mathrm{X}_{4} \mathrm{Z}$ naik satu satuan, maka kepatuhan WPOP akan naik sebesar 0,028 . 
Nilai Adjusted R Square sebesar 0,805 atau sebesar 80,5 persen. Hal tersebut menunjukkan bahwa variabel pemahaman internet memoderasi pengaruh variabel e-registration, e-SPT, e-filling, dan e-billing sebesar 80,5 persen terhadap kepatuhan wajib pajak orang pribadi, sedangkan sisanya sebesar 19,5 persen dipengaruhi oleh faktor lain diluar penelitian ini. Nilai Sig. sebesar 0,000 $<0,05$. Maka dapat disimpulkan bahwa e-registration, e-SPT, e-filling, dan e-billing dengan pemahaman internet sebagai variabel moderasi secara simultan berpengaruh terhadap kepatuhan wajib pajak orang pribadi.

Variabel pemahaman internet $(Z)$ memiliki t hitung sebesar 1,133 dengan signifikansi sebesar 0,260 yang artinya tidak signifikan. Variabel interkasi $\mathrm{X}_{1} \mathrm{Z}$ mempunyai $\mathrm{t}$ hitung sebesar 0,753 dan nilai signifikansi sebesar 0,453 (tidak signifikan). Variabel interkasi antara $\mathrm{X}_{2} \mathrm{Z}$ mempunyai t hitung sebesar $-1,819$ dan nilai signifikansi sebesar 0,072 (tidak signifikan). Variabel interkasi antara $X_{3} Z$ mempunyai $\mathrm{t}$ hitung sebesar $-0,857$ dan nilai signifikansi sebesar 0,394 (tidak signifikan). Variabel interkasi $\mathrm{X}_{4} \mathrm{Z}$ mempunyai $\mathrm{t}$ hitung sebesar 0,936 dan nilai signifikansi sebesar 0,352 (tidak signifikan).

Hasil penelitian ini menunjukkan bahwa pemahaman internet tidak mampu memoderasi hubungan antara e-registration $\left(\mathrm{X}_{1}\right)$, e-SPT $\left(\mathrm{X}_{2}\right)$, e-filing $\left(\mathrm{X}_{3}\right)$, dan ebilling $\left(\mathrm{X}_{4}\right)$ terhadap kepatuhan wajib pajak orang pribadi $(\mathrm{Y})$. Hal tersebut disebabkan karena walaupun wajib pajak memiliki pemahaman internet yang baik, dalam penggunaan e-system perpajakan dapat dilakukan oleh siapa saja sehingga wajib pajak yang tidak paham maupun paham internet dengan baik dapat meminta bantuan orang lain dalam menggunakan e-system perpajakan dalam meningkatkan kepatuhan wajib pajak orang pribadi. Misalkan meminta bantuan konsultan pajak.

Penelitian yang dilakukan oleh Yanti \& Setiawan (2020) mengenai Pengaruh Penerapan E-Filing pada Kepatuhan WPOP dengan Sosialisasi Perpajakan dan Pemahaman Internet sebagai Variabel Pemoderasi mendapatkan hasil yang sama yaitu pemahaman internet tidak dapat memoderasi pengaruh penerapan e-filing pada kepatuhan wajib pajak orang pribadi di KPP Pratama Badung."

\section{SIMPULAN}

E-registration, e-SPT, e-filing, dan e-billing berpengaruh positif terhadap kepatuhan wajib pajak orang pribadi. Hal tersebut mengindikasikan bahwa keberadaan $e-$ system perpajakan akan memermudah wajib pajak dalam mendaftarkan, membayar, dan melaporkan pajaknya yang diharapkan mampu meningkatkan kepatuhan wajib pajak. Pemahaman internet tidak dapat memoderasi hubungan antara e-registration, e-SPT, e-filing, dan e-billing terhadap kepatuhan wajib pajak orang pribadi. Hasil penelitian tersebut berarti bahwa dalam menggunakan esystem perpajakan yang meliputi e-registration, e-SPT, e-filing, dan e-billing wajib pajak yang tidak paham maupun paham mengenai internet dapat menggunakan sistem tersebut. Hal tersebut karena dalam penggunaannya dapat meminta bantuan orang lain, misalnya konsultan pajak.

Beberapa saran yang dapat diberikan dalam penelitian yaitu Bagi DJP dan KPP Pratama Gianyar, sebaiknya lebih aktif lagi dalam mendampingi wajib pajak dalam penggunaan $e$-system perpajakan. Bagi wajib pajak sebbaiknya lebih aktif lagi berkomunikasi dengan Account Representatitive (AR) jika mengalami kesulitan 
dalam penggunaan e-system perpajakan. Bagi penelitian selanjutnya, diharapkan untuk memerluas daerah penelitian, mengingat wilayah kerja KPP Pratama Gianyar hanya di Kabupaten Gianyar, Kabupaten Klungkung, Kabupaten Bangli, dan Kabupaten Karangasem.

\section{REFERENSI}

Adhiambo, O. J., \& Theuri, J. M. (2019). Effect of Taxpayer Awareness and Compliance Cost on Tax Compliance Among Small Scale Traders in Nakuru. International Academic Journal of Economics and Finance, 3(3), 279-295.

Agustiningsih, W., \& Isroah, I. (2016). Pengaruh Penerapan E-Filing, Tingkat Pemahaman Perpajakan Dan Kesadaran Wajib Pajak Terhadap Kepatuhan Wajib Pajak Di Kpp Pratama Yogyakarta. Nominal, Barometer Riset Akuntansi Dan Manajemen, 5(2). https:/ / doi.org/10.21831/nominal.v5i2.11729

Alasfour, F., Samy, M., \& Bampton, R. (2016). The determinants of tax morale and tax compliance: Evidence from Jordan. In Advances in Taxation (Vol. 23). https://doi.org/10.1108/S1058-749720160000023005

Ameur, F., \& Tkiouat, M. (2016). A contribution of expected utility theory in taxpayers' behavior modeling. International Journal of Economics and Financial Issues, 6(3), 1217-1224.

Anees, M., \& Kumar, M. M. (2017). Perception of Taxpayers' Towards E-File Adoption. International Journal of Research-Granthaalayah, 5(11), 325-332. https://doi.org/10.5281/zenodo.1117173

Badan Pusat Statistik. (2020). Realisasi Pendapatan Negara. https://www.bps.go.id/statictable/2009/02/24/1286/realisasipendapatan-negara-milyar-rupiah-2007-2020.html

Dewi, R. C., Pratiwi, H., Rahmamuthi, A., Petra, B. A., \& Ramadhanu, A. (2019). Pengaruh Sistem E-Billing Dan Kualitas Pelayanan Terhadap Kepatuhan Wajib Pajak. Jurnal Teknologi Dan Sistem Informasi Bisnis ISSN : 2655-8238, 1(2), 13-17.

Direktorat Jenderal Pajak. (2019). Tata Cara Penyampaian Surat Pemberitahuan Tahunan Bagi Wajib Pajak Orang Pribadi Menggunakan Formulir $1770 S$ dan $1770 S S$.

Ersania, G. A. R., \& Merkusiwati, N. K. L. A. (2018). Pengaruh Penerapan E-system Perpajakan Terhadap Tingkat Kepatuhan Wajib Pajak Orang Pribadi. E-Jurnal Akuntansi, 22, 1882. https://doi.org/10.24843/eja.2018.v22.i03.p09

Ghozali, I. (2016). Aplikasi Analisis Multivariate dengan Program IBM SPSS 23. BPFE Universitas Diponegoro.

Hakim, M. M. (2016). Analisis Model Penerimaan Pengguna Sistem Pelaporan Pajak Online. Simetris: Jurnal Teknik Mesin, Elektro Dan Ilmu Komputer, 7(1), 365. https://doi.org/10.24176/simet.v7i1.526

Josiah, M., Gbenga, E., Okoro, E. O., Adeboye, O. M., \& Maduku, C. (2020). Information-Technology-and-Tax-Administration-in-Nigeria. September.

Krisnayanti, N. K. Y., \& Yuesti, A. (2019). Pengaruh Kepatuhan Wajib Pajak, Pemeriksaan Pajak, Penagihan Pajak Dan Sanksi Perpajakan Terhadap Penerimaan Pajak (Pada Kantor Pelayanan Pajak Pratama Di Wilayah Denpasar Timur). 1(2), 1-40.

Laksmi Puspita Yanti, P., \& Ery Setiawan, P. (2020). Pengaruh Penerapan E-Filing 
pada Kepatuhan WPOP dengan Sosialisasi Perpajakan dan Pemahaman Internet sebagai Variabel Pemoderasi. E-Jurnal Akuntansi, 30(8), 1900. https:// doi.org/10.24843/eja.2020.v30.i08.p01

Mardiasmo. (2016). Perpajakan. Andi.

Muthmainna, N. (2017). Pengaruh Penerapan E-System Perpajakan terhadap Tingkat Kepatuhan Wajib Pajak pada Kantor Pelayanan Pajak (KPP) Pratama Bantaeng. Skripsi Fakultas Ekonomi Dan Bisnis Universitas Hasanuddin Makasar.

Nurhidayah, S. (2015). Pengaruh Penerapan Sistem E-filling Terhadap Kepatuhan Wajib Pajak Dengan Pemahaman Internet Sebagai Variabel Pemoderasi Pada KPP Pratama Klaten. 8, 1-4.

Oktaviani, R. M., Sunarto, S., \& Lita, N. (2018). Pemahaman Internet Sebagai Pemoderasi Penerapan Sistem E-Filling Terhadap Kepatuhan Wajib Pajak. Prosiding SENDI_U 2018, 575-580.

Pitić, G., Radosavljević, G., Babin, M., \& Erić, M. (2019). Digitalization of the tax administration in Serbia. Ekonomika Preduzeca, 67(1-2), 131-145. https://doi.org/10.5937/ekopre1808131p

Pratami, L. P. K. A. W., Sulindawati, N. L. G. E., \& Wahyuni, M. A. (2017). Pengaruh Penerapan E-System Perpajakan Terhadap Tingkat Kepatuhan Wajib Pajak Orang Pribadi Dalam Membayar Pajak Pada Kantor Pelayanan Pajak (Kpp) Pratama Singaraja. JIMAT (Jurnal Ilmiah Mahasiswa Akuntansi S1), 7(1). https:// doi.org/10.23887/jimat.v7i1.9462

Pringgandana, A., \& Suaryana, I. G. N. A. (2019). Faktor-Faktor yang Mempengaruhi Kemauan Membayar Pajak WPOP di Kantor Pelayanan Pajak Pratama Gianyar. E-Jurnal Akuntansi, 26, 340. https://doi.org/10.24843/eja.2019.v26.i01.p13

Purnamasari, D. I., \& Hindria, R. (2018). The Effect of Modernization of Indonesia's Tax Administration System on Tax Compliance: A Study of Small Medium Enterprises (SMEs ) Taxpayers. International Journal of Computer Networks and Communications Security, 6(3), 61-65.

Purnaningsih, N. K. C., \& Noviari, N. (2019). Pengaruh Penerapan E-Filling Terhadap Kepatuhan Wajib Pajak Orang Pribadi. E-Jurnal Akuntansi, 28(3), 1838. https://doi.org/10.24843/eja.2019.v28.i03.p13

Putra, T. Y. (2015). Pengaruh Penerapan Sistem Administrasi e-registration, e-SPT, dan e-filling Terhadap Tingkat Kepatuhan Wajib Pajak. Jurnal Administrasi Bisnis - Perpajakan (JEJAK), 6(1).

Rara Susmita, P., \& Supadmi, N. (2016). Pengaruh Kualitas Pelayanan, Sanksi Perpajakan, Biaya Kepatuhan Pajak, Dan Penerapan E-Filing Pada Kepatuhan Wajib Pajak. E-Jurnal Akuntansi, 14(2), 1239-1269.

Redae, R. B., \& Sekhon, S. (2016). Taxpayers' Knowledge and tax compliance behavioral in Ethiopia: A Study of Tigray State. International Journal of Management and Commerce Innovation, 3(2), 1090-1102.

Sabil, Lestiningsih, A. S., \& Pujiwidodo, D. (2018). Pengaruh E-Spt Pajak Penghasilan Dan Pemahaman Pajak Terhadap Kepatuhan Wajib Pajak. Jurnal SIKAP (Sistem Informasi, Keuangan, Auditing Dan Perpajakan), 2(2), 122. https://doi.org/10.32897/sikap.v2i2.67

Sentanu, I. N. W., \& Budiartha, K. (2019). Effect of taxation modernization on tax compliance. International Research Journal of Management, IT and Social Sciences, 
6(4), 207-213. https://doi.org/10.21744/irjmis.v6n4.683

Sihar, T., \& Kopong, Y. (2017). The Effect of E-Filing On The Of Compliance Individual Taxpayer. 13(1), 45-51.

Venkatesh, V., Morris, M. G., Davis, G. B., \& Davis, F. D. (2003). User Acceptance of Information Technology: Toward a Unified View. Journal of Chemical Information and Modeling, 27(03), 1689-1699.

Widjaja, H., \& Siagian, A. J. S. J. (2017). Analisis Penerapan E-System Perpajakan Pada Wajib Pajak Pribadi Terhadap Pelaksanaan Self-Assesment System Dalam Memenuhi Kewajiban Perpajakan. Jurnal Ekonomi, 22(3), 440-447. https://doi.org/10.24912/je.v22i3.279 